\title{
Early mortality in acute promyelocytic leukemia: Potential predictors (Review)
}

\author{
CAN CHEN*, XILIAN HUANG*, KAILE WANG, KUANG CHEN, DANQUAN GAO and SHENXIAN QIAN
}

Department of Hematology, Hangzhou First People's Hospital, Hangzhou, Zhejiang 310006, P.R. China

Received August 29, 2016; Accepted December 8, 2017

DOI: $10.3892 / 01.2018 .7854$

\begin{abstract}
Acute promyelocytic leukemia (APL) is a rare leukemia characterized by the balanced reciprocal translocation between the promyelocytic leukemia gene on chromosome 15 and the retinoic acid receptor $\alpha(\operatorname{RAR} \alpha)$ gene on chromosome 17, and accounts for $10-15 \%$ of newly diagnosed acute myeloid leukemia each year. The combined use of all-trans retinoic acid and arsenic trioxide (ATO) as primary therapy has markedly improved the survival rate of patients with APL. Mortality in the first 30 days following therapy remains a major contribution to treatment failure. In the present study, published data was reviewed with a focus on the factors associated with early mortality. When treated with ATO as a primary treatment, the fms-like tyrosine kinase-internal tandem deletion has no impact on early mortality. Low lymphoid enhancer binding factor-1 expression may be a reliable marker for early mortality and the target of therapy if it could be proven by further studies. Cluster of differentiation (CD)56+ and CD34+/CD2+ may be candidates to select high-risk patients. The risk of early mortality in APL still cannot be predicted via the cell surface makers, despite multiple studies on their prognostic significance. Typically, a complex translocation did not alter the survival rate in patients with APL; however, if an abnormal karyotype [e.g., Ide(17), ZBTB16/ RAR $\alpha$ and
\end{abstract}

Correspondence to: Professor Shenxian Qian, Department of Hematology, Hangzhou First People's Hospital, 216 Huansha Road, Hangzhou, Zhejiang 310006, P.R. China

E-mail: sysxqian@126.com

${ }^{*}$ Contributed equally

Abbreviations: APL, acute promyelocytic leukemia; ED, early death; EDR, early death rate; FLT3, Fms-like tyrosine kinase; PML, promyelocytic leukemia; RAR $\alpha$, retinoic acid receptor $\alpha$; ATRA, all-trans retinoic acid; ATO, arsenic trioxide; WBC, white blood cell count; M3V, microgranular variant; LEF1, lymphoid enhancer binding factor-1

Key words: acute promyelocytic leukemia, early mortality, Fms-like tyrosine kinase 3 gene, immunophenotyping, microgranular variant, lymphoid enhancer binding factor-1, complex karyotype
STAT5B/RAR $\alpha$ ] appeared singularly or as part of a complex mutation, there is a high possibility of early mortality if clinicians are unable to identify or monitor it.

\section{Contents}

1. Introduction

2. Fms-like tyrosine kinase 3 gene

3. Microgranular variant (M3V)

4. Immunophenotyping

5. Complex karyotype

6. Lymphoid enhancer binding factor-1 (LEF1)

7. Conclusion

\section{Introduction}

Acute promyelocytic leukemia (APL) is a rare leukemia characterized by the balanced reciprocal translocation between the promyelocytic leukemia (PML) gene on chromosome 15 and the retinoic acid receptor $\alpha(\operatorname{RAR} \alpha)$ gene on chromosome 17, and accounts for between 10 and $15 \%$ of newly diagnosed acute myeloid leukemia (AML) cases each year (1). Potentially life-threatening coagulopathy, and distinct morphologic and cytogenetic aberrations define APL as a unique subtype of AML (2). Early studies have demonstrated a median survival time of 1 week, ranging from 1 day to 1 month (3-6) in patients who were untreated or only received corticosteroids. The combined administration of all-trans retinoic acid receptor $\alpha$ (ATRA) and arsenic trioxide (ATO) as primary therapy has notably improved the survival rate and decreased toxicity in patients. Early death (ED; mortality in the first 30 days following therapy) remains a major contribution to treatment failure (7). A previous study analyzed the data from surveillance, epidemiology and an end result program of 1,400 APL patients, revealing an ED rate (EDR) of $17.3 \%$ (8). Due to delayed diagnosis, delayed administration of ATRA and/or inadequate supportive care, the EDR of APL did not change substantially (9); if high-risk patients could be identified earlier and provided with better supportive care, such as the hemostatic targets protocol (e.g., platelets $>30 \times 109 / 1$, normal prothrombin time, normal activated partial thromboplastin time, fibrinogen $>1.5 \mathrm{~g} / \mathrm{l})(10)$, the EDR is expected to decrease. 
In the present study, published data is reviewed with a focus on the factors that may contribute to the ED of patients with APL, in order to improve the identification of high-risk patients.

\section{Fms-like tyrosine kinase 3 (FLT3) gene}

The FLT3 gene, a class III tyrosine kinase receptor, is located on chromosome 13q12 in humans (11). Somatic mutations in AML are common, including missense mutations in the activation loop domain (ALM) of the tyrosine kinase domain (FLT3/ALM) and internal tandem duplications of the juxtamembrane domain coding sequence [FLT3-internal tandem duplication (ITD)] (12-14). It is the most frequent genetic event in APL that may coincide with $\mathrm{t}(15 ; 17)$ translocation. Several studies have demonstrated that $20-40 \%$ of APL patients possess the FLT3-ITD mutation and another 10-20\% carry an FLT3/ALM mutation $(15,16)$. Thus, Souza et al $(17)$ suggested that FLT3-ITD positive APL patients may be classified as a new sub-type.

Previous studies have identified that FLT3-ITD is associated with a high white blood cell count (WBC) (17-28), the microgranular variant (M3V) type (17-20,23,25-27), short type PML/RAR $\alpha$ [break cluster region 3 (BCR3)] (17,19,20,23,24,26,27), sex (28), low-fibrinogen concentration (22), hemoglobin levels (17,26) and high lactate dehydrogenase (LDH) level (22). However, when discussed in the context of ED, the prognostic significance of this association remains unclear.

Wing et al (18) reported 82 patients who received a primary treatment with ATRA. FLT3 aberrations were detected in 35 cases (43\%) at diagnosis, and were identified to be significantly associated with microgranular morphology and higher white blood cell count (WBC), but not the short type. A total of $7 / 19$ patients succumbing to ED were carrying the ITD mutations, and an association was identified between the FLT3-ITD mutations and ED ( $\mathrm{P}=0.06)$, male, high WBC, and microgranular morphology (17). Gale et al (20) revealed results similar to the aforementioned Wing study, reporting an FLT3 mutation rate of $43 \%$ in 203 patients, with a number of them (183/203), who were diagnosed following the availability of ATRA for the treatment of APL, receiving ATRA as primary therapy. The authors identified a significantly high EDR in the FLT3-mutated group and the presence of FLT3-ITD reduced the additional cytogenetic abnormalities accompanying $\mathrm{t}(15 ; 17)$ translocation. Furthermore, it was identified that the use of an FLT3 inhibitor CEP-701 had a greater effect on cell survival/proliferation in FLT3-ITD cells. However, it reduced the differentiation function of ATRA, which may have lead to relapse (20). Kainz et al (29) identified that FLT3-ITD was associated with early mortality in 21 APL patients, while 2/5 ED patients did not accept ATRA. Barragán et al (30) analyzed the 739 patients assigned to the Pethema and Hovon groups between 1996 and 2005, which included the PETHEMA LPA96 and Pethema/Hovon LPA99 trials, identified a significantly higher EDR in the FLT3-ITD group ( $\mathrm{P}=0.03)$, which was associated with expression of CD2, CD34, human leukocyte antigen-DR, and CD11b surface antigens. This result was similar to Souza et al (17).
Chillon et al (21) observed that patients with an initial normalized copy number of PML-RARA transcripts less than the 25th percentile experienced increased incidence of ITDs $(\mathrm{P}=0.001)$ and an adverse outcome of 5 year overall survival (OS) and relapse-free survival (RFS) but not EDR. Schnittger et al (25) identified that FLT3-ITD did not have a significant prognostic impact. Notably, when using a threshold mutation/wild-type ratio of 0.5 , the ED rate was significantly higher for those with an FLT3-ITD/wt ratio $>0.5$ $(\mathrm{P}=0.039)$. The lack of association between FLT3-ITD and ED were also observed by Kiyoi et al (22), Callens et al (19), Noguera et al (23), Breccia et al (31), Mathews et al (24) and Lucena-Araujo et al (26), however, Breccia et al (31) observed a significant association between FLT3 and OS. Due to the controversy of the EDR and FLT3-ITD mutation, Beitinjaneh et al (32) conducted a systematic review to investigate the prognostic significance of FLT3 mutations for APL. A total of 11 observational studies were included and 10 of them received ATRA as primary therapy (the other received ATO). The authors identified a negative effect with ITD on OS and disease-free survival (DFS) for APL; however, there was no impact on complete remission (CR) rates with only $6 \mathrm{CR}$ rates available in this study (32). Thus, the effect of FLT3 in APL remains difficult to determine.

In studies that used ATO as one of the introductory chemotherapeutic drugs for APL, the clinical outcomes presented were more favorable. For example, the study by Mathews et al (24) reported an ITD mutation rate of 33\% in 98 APL patients and identified no impact on outcome. A study by the Shanghai Group (33) also suggested that the status of FLT3 did not associate with low EDR in 85 patients with APL receiving ATRA/ATO, and suggested that ATO may inhibit the negative effect of ITD. In a different study, 4/124 patients succumbed during primary therapy and no adverse outcomes influenced by FLT3 mutation status were identified (10). It has been demonstrated that inferior OS and DFS were significantly associated with FLT3-ITD (24). Therefore, any adverse effect of FLT3 mutations appears to be neutralized by the addition of ATO during primary therapy and consolidation. Furthermore, the authors suggest that FLT3 inhibitor therapy will serve no function in the future management of APL despite the occurrence of FLT3 mutations in APL. Poiré et al (27) analyzed 245 newly diagnosed adult patients with APL treated on intergroup trial C9710 and identified that FLT3 status had no association with EDR. The same result was also examined by Stock et al (16) in their study of 78 adults with newly diagnosed APL entered onto CALGB 9710, a North American Intergroup phase III trial. However, the authors suggested that targeted therapy with FLT3 inhibitors may improve relapse free survival for patients with FLT3 + APL.

The ITD mutation may have a relatively reduced function in the progression of APL and early mortality in patents that did not receive ATO as the initial chemotherapy. However, when ATO was used as a primary therapy, the inferior outcome was observed to be reversed. Continued study may resolve the mechanism of this phenomenon. Due to limitations in patient numbers and selection, more retrospective or prospective studies should focus on FLT3-ITD and early mortality in patients that received ATO as a first induction chemotherapy regimen. 


\section{Microgranular variant (M3V)}

M3V is defined as leukemia promyelocytes with few Auer rods (34) and are devoid of or have only sparse granules (35). The incidence of this sub-type was $15-25 \%$ in APL. Several studies reported that M3v is associated with an increased white blood cell count $(25,36,37)$, FLT3-ITD-mutations (17-20,23-28,37,38), the expression of CD2 (35-37,39-46) and CD34 (40,41), the relative incidence of the bcr-3 sub-type $(37,39,47)$ and an increased platelet count (48). However, data regarding the prognostic significance of M3v of APL is rare, particularly in patients receiving ATRA and ATRA/ATO regimens.

Bassan et al (49) observed that M3v was associated with a higher incidence of ED in the conventional chemotherapy regimens, similar to the results of Cunningham et al (50). However, not all studies observed the same results. Davey et al (48) identified no impact of M3v on the early mortality of patients with APL in the chemotherapy regimens. The lack of significant impact of M3v on prognosis was also observed by Schnittger et al, however, their data did not identify the induction therapy of patients (25).

Utilizing ATRA as first therapy of APL, Tallman et al (7) identified no effect on ED in APL. Additionally, Kuchenbauer et al (51) suggested that the impact of poor prognosis of M3v in APL is associated with the frequency of FLT3-ITD mutation. Co-expression of FLT3-ITD yields an increased frequency of M3v with hypogranular blasts in lobulated nuclei (52). Thus Gale et al (20) suggest that the ITD may contribute to the generation of morphologic features of M3v. However, other studies (53-55) have published gene expression of a cohort of patients with APL and identified a gene group to distinguish M3 from M3v. The authors suggest that genes more suited to differentiate M3 from M3v are not markedly associated with FLT3-ITD $(53,54)$ and morphology and FLT3 status partly affect gene expression independently (54). Other clinical data suggested that $\mathrm{M} 3 \mathrm{v}$ is an independent factor in predicting a poor prognosis, and therefore not influenced by FLT3-ITD $(18,19,23)$. A large study of 155 patients with APL focused on the outcome of patients with M3v (37), and identified no difference in morphology when treated with ATRA regimens when adjusting for $\mathrm{WBC}$ or relapse risk score ( $\mathrm{P}=0.02$, without adjustment). The authors also suggest that the poor outcome of $\mathrm{M} 3 \mathrm{v}$ in previous studies may be due to the expression of $\mathrm{CD} 2$. Thus whether M3v is an independent predict mark of ED of APL remains unresolved.

\section{Immunophenotyping}

CD56, which is known as a neural cell adhesion molecule and associated with unfavorable clinical outcome in AML with $t(8 ; 21)(56)$, is expressed in 11-15\% of patients with APL (57-59). It has been associated with CD2+ (57), CD34+ (57,59), CD7+ (57), HLA-DR+ (57), CD15+ (57), CD117+ (57), $\mathrm{BCR} 3$ isoform $(57,60,61)$, fibrinogen range $(60)$, and a trend toward M3v, CD11b+ and CD9+ has been demonstrated (57). Murray et al (60) first described a decreased CR rate associated with expression of CD56 and noticed the association between CD56 and natural killer and T cell markers. The association between CD56+ and immaturity-associated markers (CD117) and natural killer and T-cell antigens, including CD2 and CD7 has been identified and it is hypothesized that these sub-groups of APL may have arisen in progenitors that have not undergone lineage restriction (57). The immature, undifferentiated and pluripotent leukemic stem cells are less sensitive to the primary therapy, which may explain why the CD56+ group experienced a decreased CR rate and an increased EDR (57). Ito et al (59) did not identify any impact of CD56+ on EDR in their study of 28 patients with APL. Similar results were also obtained by Ferrara et al (58), however, the authors observed that CD56 is an independent prognostic impact on survival that includes WBC count which indicated that the poor outcome of CD56+ APL is not associated with high WBC count. However, when drugs including ATO and gemtuzumab ozogamicin were administered as primary treatment, the predicted value of CD56 is waiting to be verified in the future studies (62).

The T-cell associated antigen CD2 was associated with PML/RAR $\alpha$ bcr3 $(44,46,63)$, M3v $(39,42,46,64)$ and increased leukocyte counts $(46,63)$. In one study, CD2 predicted an improved CR rate and event-free survival (EFS) in APL (46). $\mathrm{Xu}$ et al (65) used a threshold value of $20 \%$ of positive cells to distinguish $\mathrm{CD} 2+$ to $\mathrm{CD} 2-\mathrm{APL}$ and identified that $\mathrm{CD} 2+\mathrm{APL}$ had an increased EDR and is an independent risk factor of ED. The existing data of CD2 in APL is rare, therefore it cannot be confirmed whether this immunophenotyping will affect the prognosis.

The frequency of CD34 expression has been identified to range from 20 to $31 \%(28,35,45,46)$. The expression of CD34 in APL has been associated with leukocytosis $(45,46,64,66,67)$, bcr3 isoform $(45,46,64,63)$, M3V $(45,46,64,63)$, increased frequency in females (45) and CD2 expression $(45,46,64,63)$. It is often expressed at a significantly lower density on the surface of APL compared to AML $(41,64)$. Breccia et al (63) and other studies $(45,46)$ did not identify any association between early mortality and isolated CD34 expression, however, shorter OS was observed. A study of 40 de novo APL patients with a $\mathrm{CD} 34+$ rate of $32.5 \%$ confirmed a significantly increased EDR of CD34+ APL (66).

Grimwade et al (67) suggested that the CD2+ APL cell may derive from a different stem cell co-expressing CD2 and myeloid antigens. Thus, Breccia et al (63) continue to focus on the patients with CD34/CD2 double positive APL. The authors suggest that these patients may be identified as a subgroup with characteristic features associated with M3v, Bcr 3, FLT3-ITD, high incidence of differentiation syndrome and disseminated intravascular coagulation (DIC). This result was not consistent with the data of Albano et al (45) who identified no differences between the groups of complete remission, overall survival and disease-free survival, however, the authors did not evaluate the impact of CD34/CD2 on EDR. The poor clinical characteristics of this sub-type may predict a higher EDR and future studies may prove it.

A study (68) of 231 APL patients receiving various primary treatment suggested that carriers of a $\mathrm{G}>\mathrm{A}$ polymorphism at position 1377 in the core promoter of the CD95 cell death receptor gene may predict a poor prognosis, particularly for ED $(\mathrm{P}=0.01)$ with patients more likely to suffer infection-associated mortality. This genetic variation may be a reliable marker of ED in future studies. CD15 has been reported (60) to exhibit an unexpectedly high frequency 
of relapses and a low OS. However the authors exclude the ED patients in this study, thus no data is available to reveal an association between ED and CD15.

\section{Complex karyotype}

The balanced reciprocal translocation $\mathrm{t}(15 ; 17)$ (q22;q11-21) leading to PML gene and RARA gene fusion is the genetic characteristic of APL. The classical $t(15 ; 17)(\mathrm{q} 22 ; \mathrm{q} 12)$ is observed in between 70 and $90 \%$ of APL cases (69), and a number of patients exhibit complex translocations, involving chromosomes 15, 17 and other chromosomes (70,71). The most common abnormality is trisomy $8(72,73)$. A number of the complex mutations were sensitive for the prediction of ED in APL. In a study by De Botton et al (73) and the Southwest Oncology Group (74), additional cytogenetic changes in patients with $\mathrm{t}(15 ; 17)$ had no effect on the CR rate, EFS, relapse and overall survival at 2 years, which is in accordance with the findings of Grimwade et al (72). Mi et al (75) identified that a complex karyotype may contribute to an improved prognosis. Other reports have suggested the presence of complex karyotype changes adversely affects prognosis (76). A study of C9710 analyzed 245 newly diagnosed adult patients with APL (27). The authors identified a significantly lower $\mathrm{CR}$ rate in the complex karyotype [two or more additional chromosomal abnormalities (ACAs)] subgroup compared with one ACA or normal karyotype $(\mathrm{P}=0.001)$ independent of ATO treatment. This may be due to the reduced sensitivity to ATRA/ATO and the delay in administering ATO, which has been demonstrated by an Italian/German/Austrian cooperative group study that suggested earlier administration of ATO may overcome the negative effect of complex karyotypes (77). The natural resistance to primary therapy is also a factor contributing to ED in patients with APL.

Tetraploidy is rare and accounts for $0.75 \%$ in APL (78). Published data revealed a variety of clinical features of this mutation. CD2 was observed to be more frequent in this group (7 of 15) compared with the literature reported $23 \%$ of normal APL $(39,42,44,45,64)$. It is more common in males with a median age of 49 (78). Since the majority of these cases did not acquire other complex mutations, the outcomes remain favorable despite the higher expression of CD2. The ATRA based primary therapy may be suitable for this complex mutation.

Co-expression of $\mathrm{t}(8 ; 21)$ and $\mathrm{t}(15 ; 17)$ is rare in APL, with only 6 patients reported at present (79-84). Neto et al (79) reported a case of APL-M3V which was sensitive to ATRA treatment, and detected a novel $\mathrm{t}(8 ; 21)$ chromosomal aberration between 3 and 18 months after initial treatment. The authors noted the intermittent detection of $t(8 ; 21)$ during periods without ATRA suggested there was an antitumor effect of ATRA on M2 leukemic cells. Charrin et al (80) and Bonomi et al (81) reported two cases and identified that the $t(15 ; 17)$ may be acquired subsequent to $t(8 ; 21)$. A total of 5 patients received the ATRA-based treatment and achieved CR. No ED occurred during primary therapy, despite a high rate of relapse. A favorable response to chemotherapeutic induction indicated that the ATRA and idarubicin and Ara-C induction treatment was suitable for this complex karyotype (84). Another study also suggested that at the time of diagnosis the rate of M2 leukemic cells could be tested using polymerase chain reaction detection and the alteration of bone marrow cell kinetics may trigger $t(8 ; 21)$ via complex mechanisms following chemotherapy (79).

Ider(17), which has been reported in only 72 APL cases globally, is a relatively rare variant cytogenetic abnormality among patients with APL $(83,85-97)$. This isochromosomal abnormality may occur following initial reciprocal translocation of $\mathrm{t}(15 ; 17)$, and is formed from the short arm and duplication of the long arm of ider(17)t(15;17) (85). Clinical outcome data were available for 36 patients with a CR rate of $77.8 \%$ and the response to ATRA and EDR were observed to be similar to that in normal APL. A total of 19 patients succumbed to the disease; however, the prognostic significance of this abnormal karyotype remains unclear due to the limited number of cases. The proportion of cells with the ider(17)(q10)t(15;17) is higher, in 9/12 cases. Since tumor protein p53 (TP53) is located on $17 \mathrm{p}$, the ider(17)(q10)t $(15 ; 17)$ may provide a growth advantage to the relevant clone (85). The long type PMA/RAR $\alpha$ is prevalent in this type (57\%). Bcrl splicing PML exon 5-6 was associated with decreased sensitivity to ATRA (98), which may explain the ATRA resistance of ider(17) patients. Since the loss of TP53 and absence of PML exon 5 may occur in this rare subtype and present data have identified a trend of poor outcome, ider(17) is a candidate for further study.

The nuclear receptor binding SET domain protein 3, lysine acetyltransferase $6 \mathrm{~A}$ and fibroblast growth factor receptor 1 which regulate cell transcription (99) and are associated with the stem cell myeloproliferative disorder are candidate genes involved with the loss of $8 \mathrm{p}(100)$. Otero et al (101) reported a patient with APL with dicentric $t(8 ; 13)(q 10 ; q 10)$ who succumbed due to a central nervous system hemorrhage on day 3 with ATRA based primary therapy. The authors hypothesized that the additional chromosomal changes were directly associated with the patient's prognosis, and that the novel chromosomal abnormalities may predict a poor outcome of APL.

Between 1 and 2\% of APL cases are due to abnormal translocations including zinc finger and BTB domain containing 16 (ZBTB16)/RAR $\alpha$, nucleophosmin (NPM)/RAR $\alpha$, nuclear matrix associated/RAR $\alpha$, signal transducer and activator of transcription 5B (STAT5B)/RAR $\alpha$, protein kinase CAMP-dependent type 1 regulatory subunit $\alpha /$ RAR $\alpha$, BCL6 corepressor/RAR $\alpha$ and factor interacting with PAPOLA and SPSF1/RAR $\alpha$, and all these translocations involve RARA (70). A review by Adams and Nassiri (102) discussed the various translocations of APL and identified certain features. $t(5 ; 17) \mathrm{NPM} / \mathrm{RAR} \alpha$ has been diagnosed in patients younger than 10 years which is uncommon to normal APL (103). It responds well to ATRA but has higher risk of relapse. Diagnosis of ZBTB16/RAR $\alpha \mathrm{t}(11 ; 17)$ APL can be difficult. This translocation is more commonly associated with CD56 expression (104). Patients had an increased number of hypogranular pelgeroid neutrophils and a more regular nucleus compared with the bilobed nucleus typically found in APL (97). The majority of the translocations in APL can be successfully treated with ATRA/ATO, while patients with ZBTB16/RAR $\alpha$ and STAT5B/RAR $\alpha$ are resistant to ATRA and experienced a poor prognosis (105). There is currently limited data regarding the prognosis of patients with abnormal translocations. ZBTB16/RAR $\alpha$ and STAT5B/RAR $\alpha$ are 


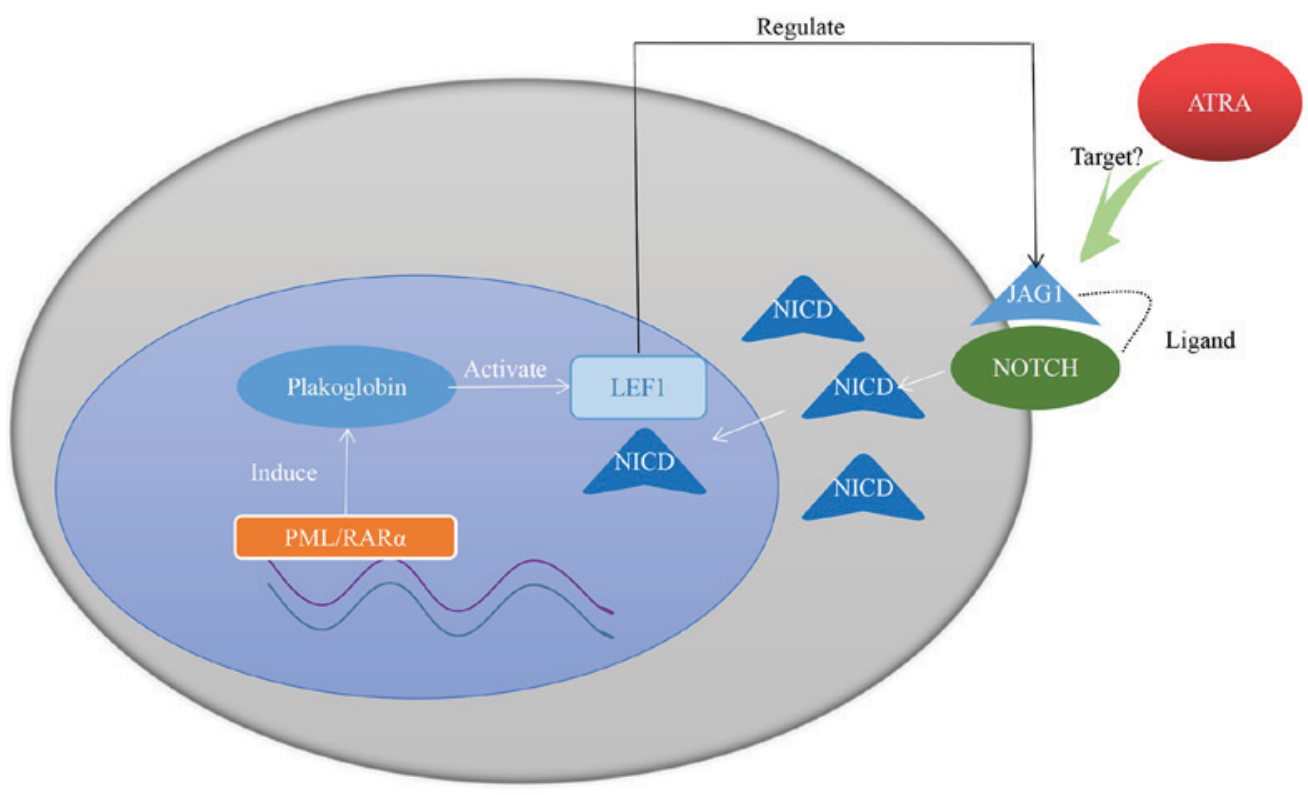

Figure 1. The hypothetic mechanism of LEF1 in the Notch signaling pathway. In the nucleus, PML/RAR $\alpha$ fusion gene may induce plakoglobin $(\gamma$-catenin) expression, leading to transcriptional activation of LEF1. LEF1 itself is a coactivator of NICD and may crosstalk with the Notch signaling pathway by regulating the expression of JAG1 on the cytomembrane. Furthermore, JAG1 is overexpressed in APL, and upon receiving ATRA therapy, it is downregulated in the NB4 cell line which indicates that JAG1 may be a therapeutic target of ATRA. PML, promyelocytic leukemia; RAR $\alpha$ retinoic acid receptor $\alpha$; LEF1, lymphoid enhancer binding factor-1; NICD, Notch intracellular domain; APL, acute promyelocytic leukemia; ATRA, all-trans retinoic acid; JAG1, Jagged 1.

associated with ED, while other variant translocations may result in a similar outcome to cases with $\mathrm{t}(15 ; 17)$ APL.

\section{Lymphoid enhancer binding factor-1 (LEF1)}

As an important member of the LEF/T-cell factor (TCF) family, LEF1 regulates cellular proliferation and cell cycle regulation (106). It is traditionally regarded as a central mediator of the wingless-type (Wnt) signaling pathway $(106,107)$ and may serve a function in development and cancerogenesis, control self-renewal, cell proliferation and differentiation (108). Previous data reveal that it may serve a vital function in early hematopoiesis and leukemic transformation in murine models (109). However, certain functions independent of wnt signaling have also been reported $(107,110)$. A study of 78 adult patients with APL (111) suggests a novel mechanism whereby LEF1 serves a specific function in the Notch signaling pathway and draws the conclusion that patients with APL overexpressing LEF1 are more likely to experience a favorable outcome.

In the nucleus, PML/RAR $\alpha$ fusion gene is able to induce plakoglobin ( $\gamma$-catenin) expression in primary patient samples as well as in cell lines, leading to transcriptional activation of LEF1 (112). LEF1 itself is a coactivator of Notch intracellular domain (107). Jagged1 (JAG1) is a downstream target gene of LEF1 and is also the ligand of Notch (113). LEF1 is able to crosstalk with the Notch signaling pathway by regulating the expression of JAG1 on the cytomembrane (112). Furthermore, JAG1 is more frequently expressed in APL and, when receiving ATRA therapy, JAG1 is downregulated in the NB4 cell line $(114,115)$. Taken together, these studies indicate that JAG1 may be a therapeutic target of ATRA, with high expression of LEF1 promoting the curative effect of ATRA. The hypothesized mechanism is presented in Fig. 1.
In trials, 103 newly diagnosed APL patients were observed and treated with the AIDA-0493 (116) and AIDA-2000 (117) protocols between January 1996 and December 2012. The median follow-up time was 5.7 years. Patients were divided in two groups according to the expression level of LEF1: A low LEF1 group with LEF1 values below the median value $(<2.1$ fold-change) and a high LEF1 group with LEF1 values above the median value ( $>2.1$ fold-change). Fisher's exact test for categorical data and the nonparametric Mann-Whitney U test for continuous variables were used to identify the difference between two groups. Survival curves and influence factors of survival endpoints were measured by the Kaplan-Meier method and multivariate Cox proportional hazards models accordingly. They demonstrated that the LEF-high group exhibited lower WBC counts $(\mathrm{P}<0.0001)$, trended towards a younger age $(\mathrm{P}=0.08)$, and presented more frequent FLT3-ITD mutations $(\mathrm{P}=0.02)$. ED only occurred in the LEF-low group $(n=9 ; P=0.002)$. This suggests that the expression of LEF may be studied as a novel marker of risk in APL if similar results can be confirmed by further studies.

\section{Conclusion}

In conclusion, published data has been reviewed with a focus on the factors associated with ED. When treated with ATO as primary treatment, the FLT3-ITD has no impact on ED. Low LEF expression may be a reliable marker of ED and a therapeutic target if it can be proven by further studies. CD56+ and CD34+/CD2+ may be candidates to select high-risk patients. High-risk patients still cannot be identified via the cell surface makers, despite a number of studies analyzing their prognostic significance. Complex translocations did not reduce the EDR in APL; however, if an abnormal karyotype [e.g., Ide(17), ZBTB16/RAR $\alpha$ and STAT5B/ RAR $\alpha$ ] appeared singularly or 
as part of a complex mutation, there is a high possibility of early mortality if clinicians are unable to identify or monitor it.

\section{References}

1. Tallman MS and Altman JK: How I treat acute promyelocytic leukemia. Blood 114: 5126-5135, 2009.

2. Bennett JM, Catovsky D, Daniel MT, Flandrin G, Galton DA, Gralnick HR and Sultan C: A variant form of hypergranular promyelocytic leukaemia (M3). Br J Haematol 44: 169-170, 1980.

3. Cooperberg AA and Neiman GM: Fibrinogenopenia and fibrinolysis in acute myelogenous leukemia. Ann Intern Med 42: 706-711, 1955

4. Van Creveld S and Mochtar IA: Fibrinolysis in acute leukemia. Maandschr Kindergeneeskd 27: 133-44, 1959 (In Dutch).

5. Ghitis J: Acute promyelocytic leukemia? Blood 21: 237-240, 1963.

6. Larson RA, Kondo K, Vardiman JW, Butler AE, Golomb HM and Rowley JD: Evidence for a 15;17 translocation in every patient with acute promyelocytic leukemia. Am J Med 76: 827-841, 1984.

7. Tallman MS, Andersen JW, Schiffer CA, Appelbaum FR, Feusner JH, Woods WG, Ogden A, Weinstein H, Shepherd L, Willman C, et al: All-trans retinoic acid in acute promyelocytic leukemia: Long-term outcome and prognostic factor analysis from the North American Intergroup protocol. Blood 100 4298-4302, 2002.

8. Park JH, Qiao B, Panageas KS, Schymura MJ, Jurcic JG, Rosenblat TL, Altman JK, Douer D, Rowe JM and Tallman MS: Early death rate in acute promyelocytic leukemia remains high despite all-trans retinoic acid. Blood 118: 1248-1254, 2011

9. Watts JM and Tallman MS: Acute promyelocytic leukemia: What is the new standard of care? Blood Rev 28: 205-212, 2014.

10. Iland HJ, Bradstock K, Supple SG, Catalano A, Collins M, Hertzberg M, Browett P, Grigg A, Firkin F, Hugman A, et al All-trans-retinoic acid, idarubicin, and IV arsenic trioxide as initial therapy in acute promyelocytic leukemia (APML4). Blood 120: 1570-1580, 2012.

11. Matthews W, Jordan CT, Wiegand GW, Pardoll D and Lemischka IR: A receptor tyrosine kinase specific to hematopoietic stem and progenitor cell-enriched populations. Cell 65 1143-1152, 1991.

12. Meshinchi S, Alonzo TA, Stirewalt DL,Zwaan M,Zimmerman M, Reinhardt D, Kaspers GJ, Heerema NA, Gerbing R, Lange BJ and Radich JP: Clinical implications of FLT3 mutations in pediatric AML. Blood 108: 3654-3661,2006.

13. Thiede C, Steudel C, Mohr B, Schaich M, Schäkel U, Platzbecker U, Wermke M, Bornhäuser M, Ritter M, Neubauer A, et al: Analysis of FLT3-activating mutations in 979 patients with acute myelogenous leukemia: Association with FAB subtypes and identification of subgroups with poor prognosis. Blood 99: 4326-4335, 2002

14. Kottaridis PD, Gale RE, Frew ME, Harrison G, Langabeer SE, Belton AA, Walker H, Wheatley K, Bowen DT, Burnett AK, et al: The presence of a FLT3 internal tandem duplication in patients with acute myeloid leukemia (AML) adds important prognostic information to cytogenetic risk group and response to the first cycle of chemotherapy: Analysis of 854 patients from the United Kingdom Medical Research Council AML 10 and 12 trials. Blood 98: 1752-1759, 2001

15. Shih LY, Kuo MC, Liang DC, Huang CF, Lin TL, Wu JH, Wang PN, Dunn P and Lai CL: Internal tandem duplication and Asp835 mutations of the FMS-like tyrosine kinase 3 (FLT3) gene in acute promyelocytic leukemia. Cancer 98: 1206-1216, 2003.

16. Stock W, Najib K, Moser BK, Powell BL, Holowka N, Gulati K, Bloomfield CD, Larson RA and Sher D: High incidence of FLT3 mutations in adults with acute promyelocytic leukemia (APL): Correlation with diagnostic features and treatment outcome (CALGB 9710). J Clin Oncol 26 (15 Suppl): S7002, 2008.

17. Souza Melo CP, Campos CB, Dutra ÁP, Neto JC, Fenelon AJ Neto AH, Carbone EK, Pianovski MA, Ferreira AC and Assumpcão JG: Correlation between FLT3-ITD status and clinical, cellular and molecular profiles in promyelocytic acute leukemias. Leuk Res 39: 131-137, 2015.

18. Au WY, Fung A, Chim CS, Lie AK, Liang R, Ma ES, Chan CH, Wong KF and Kwong YL: FLT-3, aberrations in acute promyelocytic leukaemia: Clinicopathological associations and prognostic impact. Br J Haematol 125: 463-469, 2004.
19. Callens C, Chevret S, Cayuela JM, Cassinat B, Raffoux E, de Botton S, Thomas X, Guerci A, Fegueux N, Pigneux A, et al: Prognostic implication of FLT3 and Ras gene mutations in patients with acute promyelocytic leukemia (APL): A retrospective study from the European APL Group. Leukemia 19: 1153-1160, 2005.

20. Gale RE, Hills R, Pizzey AR, Kottaridis PD, Swirsky D, Gilkes AF, Nugent E, Mills KI, Wheatley K, Solomon E, et al: Relationship between FLT3 mutation status, biologic characteristics, and response to targeted therapy in acute promyelocytic leukemia. Blood 106: 3768-3776, 2005.

21. Chillón MC, Santamaría C, García-Sanz R, Balanzategui A, Sarasquete ME, Alcoceba M, Marín L, Caballero MD, Vidriales MB, Ramos F, et al: Long FLT3 internal tandem duplications and reduced PML-RAR $\alpha$ expression at diagnosis characterize a high-risk subgroup of acute promyelocytic leukemia patients. Haematologica 95: 745-751, 2010.

22. Kiyoi H, Naoe T, Yokota S, Nakao M, Minami S, Kuriyama K, Takeshita A, Saito K, Hasegawa S, Shimodaira S, et al: Internal tandem duplication of FLT3 associated with leukocytosis in acute promyelocytic leukemia. Leukemia study group of the ministry of health and welfare (Kohseisho). Leukemia 11: 1447-1452, 1997.

23. Noguera NI, Breccia M, Divona M, Diverio D, Costa V, De Santis S, Avvisati G, Pinazzi MB, Petti MC, Mandelli F and Lo Coco F: Alterations of the FLT3 gene in acute promyelocytic leukemia: Association with diagnostic characteristics and analysis of clinical outcome in patients treated with the Italian AIDA protocol. Leukemia 16: 2185-2189, 2002

24. Mathews V, Thomas M, Srivastava VM, George B, Srivastava A and Chandy M: Impact of FLT3 mutations and secondary cytogenetic changes on the outcome of patients with newly diagnosed acute promyelocytic leukemia treated with a single agent arsenic trioxide regimen. Haematologica 92: 994-995, 2007.

25. Schnittger S, Bacher U, Haferlach C, Kern W, Alpermann T and Haferlach T: Clinical impact of FLT3 mutation load in acute promyelocytic leukemia with $\mathrm{t}(15 ; 17) / \mathrm{PML}-\mathrm{RARA}$. Haematologica 96: 1799-1807, 2011.

26. Lucena-Araujo AR, Kim HT, Jacomo RH, Melo RA, Bittencourt R, Pasquini R, Pagnano K, Fagundes EM, Chauffaille Mde L, Chiattone CS, et al: Internal tandem duplication of the FLT3 gene confers poor overall survival in patients with acute promyelocytic leukemia treated with all-trans retinoic acid and anthracycline-based chemotherapy: An international consortium on acute promyelocytic leukemia study. Ann Hematol 93: 2001-2010, 2014

27. Poiré X, Moser BK, Gallagher RE, Laumann K, Bloomfield CD, Powell BL, Koval G, Gulati K, Holowka N, Larson RA, et al: Arsenic trioxide in front-line therapy of acute promyelocytic leukemia (C9710): Prognostic significance of FLT3 mutations and complex karyotype. Leuk Lymphoma 55: 1523-1532, 2014.

28. Daver N, Kantarjian H, Marcucci G, Pierce S, Brandt M, Dinardo C, Pemmaraju N, Garcia-Manero G, O'Brien S, Ferrajoli A, et al: Clinical characteristics and outcomes in patients with acute promyelocytic leukaemia and hyperleucocytosis. Br J Haematol 168: 646-653, 2015.

29. Kainz B, Heintel D, Marculescu R, Schwarzinger I, Sperr W, Le T, Weltermann A, Fonatsch C, Haas OA, Mannhalter C, et al: Variable prognostic value of FLT3 internal tandem duplications in patients with de novo AML and a normal karyotype, $\mathrm{t}(15 ; 17)$, $\mathrm{t}(8 ; 21)$ or inv(16). Hematol J 3: 283-289, 2002.

30. Barragán E, Montesinos P, Camos M, González M, Calasanz MJ, Román-Gómez J, Gómez-Casares MT, Ayala R, López J, Fuster O, et al: Prognostic value of FLT3 mutations in patients with acute promyelocytic leukemia treated with all-trans retinoic acid and anthracycline monochemotherapy. Haematologica 96: 1470-1477, 2011.

31. Breccia M, Loglisci G, Loglisci MG, Ricci R, Diverio D, Latagliata R, Foà R and Lo-Coco F: FLT3-ITD confers poor prognosis in patients with acute promyelocytic leukemia treated with AIDA protocols: Long-term follow-up analysis. Haematologica 98: e161-e163, 2013.

32. Beitinjaneh A, Jang S, Roukoz H and Majhail NS: Prognostic significance of FLT3 internal tandem duplication and tyrosine kinase domain mutations in acute promyelocytic leukemia: A systematic review. Leuk Res 34: 831-836, 2010.

33. Hu J, Liu YF, Wu CF, Xu F, Shen ZX, Zhu YM, Li JM, Tang W, Zhao WL, Wu W, et al: Long-term efficacy and safety of all-trans retinoic acid/arsenic trioxide-based therapy in newly diagnosed acute promyelocytic leukemia. Proc Natl Acad Sci USA 106: 3342-3347, 2009 
34. Shaft D, Shtalrid M, Berebi A, Catovsky D and Resnitzky P: Ultrastructural characteristics and lysozyme content in hypergranular and variant type of acute promyelocytic leukaemia. $\mathrm{Br} \mathbf{J}$ Haematol 103: 729-739, 1998.

35. Mandelli F, Diverio D, Avvisati G, Luciano A, Barbui T, Bernasconi C, Broccia G, Cerri R, Falda M, Fioritoni G, et al: Molecular remission in PML/RAR alpha-positive acute promyelocytic leukemia by combined all-trans retinoic acid and idarubicin (AIDA) therapy. Gruppo Italiano-Malattie Ematologiche Maligne dell'Adulto and Associazione Italiana di Ematologia ed Oncologia Pediatrica Cooperative Groups. Blood 90: 1014-1021, 1997.

36. McKenna RW, Parkin J, Bloomfield CD, Sundberg RD and Brunning RD: Acute promyelocytic leukaemia: A study of 39 cases with identification of a hyperbasophilic microgranular variant. Br J Haematol 50: 201-214, 1982.

37. Tallman MS, Kim HT, Montesinos P, Appelbaum FR, de la Serna J, Bennett JM, Deben G, Bloomfield CD, Gonzalez J, Feusner JH, et al: Does microgranular variant morphology of acute promyelocytic leukemia independently predict a less favorable outcome compared with classical M3 APL? A joint study of the North American Intergroup and the PETHEMA Group. Blood 116: 5650-5659, 2010.

38. Kutny MA, Moser BK, Laumann K, Feusner JH, Gamis A, Gregory J, Larson RA, Powell BL, Stock W, Willman CL, et al: FLT3 mutation status is a predictor of early death in pediatric acute promyelocytic leukemia: A report from the Children's Oncology Group. Pediatr Blood Cancer 59: 662-667, 2012.

39. Biondi A, Luciano A, Bassan R, Mininni D, Specchia G, Lanzi E, Castagna S, Cantù-Rajnoldi A, Liso V, Masera G, et al: CD2 expression in acute promyelocytic leukemia is associated with microgranular morphology (FAB M3v) but not with any PML gene breakpoint. Leukemia 9: 1461-1466, 1995.

40. Foley R, Soamboonsrup P, Carter RF, Benger A, Meyer R, Walker I, Wan Y, Patterson W, Orzel A, Sunisloe L, et al: CD34-positive acute promyelocytic leukemia is associated with leukocytosis, microgranular/hypogranular morphology, expression of CD2 and ber3 isoform. Am J Hematol 67: 34-41, 2001.

41. Paietta E, Goloubeva O, Neuberg D, Bennett JM, Gallagher R, Racevskis J, Dewald G, Wiernik PH and Tallman MS; Eastern Cooperative Oncology Group: A surrogate marker profile for PML/RAR alpha expressing acute promyelocytic leukemia and the association of immunophenotypic markers with morphologic and molecular subtypes. Cytometry B Clin Cytom 59: 1-9, 2004

42. Maslak P, Miller WH Jr, Heller G, Scheinberg DA, Dmitrovsky E and Warrell RP Jr: CD2 expression and PML/RAR-alpha transcripts in acute promyelocytic leukemia. Blood 81: 1666 1993.

43. Reading CL, Estey EH, Huh YO, Claxton DF, Sanchez G, Terstappen LW, O'Brien MC, Baron S and Deisseroth AB: Expression of unusual immunophenotype combinations in acute myelogenous leukemia. Blood 81: 3083-3090, 1993.

44. Claxton DF, Reading CL, Nagarajan L, Tsujimoto $\mathrm{Y}$, Andersson BS, Estey E, Cork A, Huh YO, Trujillo J and Deisseroth $\mathrm{AB}$ : Correlation of $\mathrm{CD} 2$ expression with PML gene breakpoints in patients with acute promyelocytic leukemia. Blood 80: 582-586, 1992

45. Albano F, Mestice A, Pannunzio A, Lanza F, Martino B, Pastore D, Ferrara F, Carluccio P, Nobile F, Castoldi G, et al: The biological characteristics of CD34+CD2+ adult acute promyelocytic leukemia and the CD34 CD2 hypergranular (M3) and microgranular (M3v) phenotypes. Haematologica 91: 311-316, 2006

46. Guglielmi C, Martelli MP, Diverio D, Fenu S, Vegna ML, Cantù-Rajnoldi A, Biondi A, Cocito MG, Del Vecchio L, Tabilio A, et al: Immunophenotype of adult and childhood acute promyelocytic leukaemia: Correlation with morphology, type of PML gene breakpoint and clinical outcome. A cooperative Italian study on 196 cases. Br J Haematol 102: 1035-1041, 1998.

47. Gallagher RE, Willman CL, Slack JL, Andersen JW, Li YP, Viswanatha D, Bloomfield CD, Appelbaum FR, Schiffer CA, Tallman MS and Wiernik PH: Association of PML-RAR alpha fusion mRNA type with pretreatment hematologic characteristics but not treatment outcome in acute promyelocytic leukemia: An intergroup molecular study. Blood 90: 1656-1663, 1997.

48. Davey FR, Davis RB, MacCallum JM, Nelson DA, Mayer RJ, Ball ED, Griffin JD, Schiffer CA and Bloomfield CD: Morphologic and cytochemical characteristics of acute promyelocytic leukemia. Am J Hematol 30: 221-227, 1989.
49. Bassan R, Battista R, Viero P, d'Emilio A, Buelli M, Montaldi A, Rambaldi A, Tremul L, Dini E and Barbui T: Short-term treatment for adult hypergranular and microgranular acute promyelocytic leukemia. Leukemia 9: 238-243, 1995.

50. Cunningham I, Gee TS, Reich LM, Kempin SJ, Naval AN and Clarkson BD: Acute promyelocytic leukemia: Treatment results during a decade at Memorial Hospital. Blood 73: 1116-1122, 1989.

51. Kuchenbauer F, Schoch C, Kern W, Hiddemann W, Haferlach T and Schnittger S: Impact of FLT3, mutations and promyelocytic leukaemia-breakpoint on clinical characteristics and prognosis in acute promyelocytic leukaemia. Br J Haematol 130: 196-202, 2005.

52. Sohal J, Phan VT, Chan PV, Davis EM, Patel B, Kelly LM, Abrams TJ, O'Farrell AM, Gilliland DG, Le Beau MM and Kogan SC: A model of APL with FLT3 mutation is responsive to retinoic acid and a receptor tyrosine kinase inhibitor, SU11657. Blood 101: 3188-3197, 2003

53. Haferlach T, Kohlmann A, Schnittger S, Dugas M, Hiddemann W, Kern W and Schoch C: AML M3 and AML M3 variant each have a distinct gene expression signature but also share patterns different from other genetically defined AML subtypes. Genes Chromosomes Cancer 43: 113-127, 2005.

54. Marasca R, Maffei RP, Zucchini P, Castelli I, Saviola A, Martinelli S, Ferrari A, Fontana M, Ravanetti S and Torelli G: Gene expression profiling of acute promyelocytic leukaemia identifies two subtypes mainly associated with flt 3 mutational status. Leukemia 20: 103-114, 2006.

55. Yamamoto Y, Kiyoi H, Nakano Y, Suzuki R, Kodera Y, Miyawaki S, Asou N, Kuriyama K, Yagasaki F, Shimazaki C, etal: Activating mutation of D835 within the activation loop of FLT3 in human hematologic malignancies. Blood 97: 2434-2439, 2001.

56. Baer MR, Stewart CC, Lawrence D, Arthur DC, Byrd JC, Davey FR, Schiffer CA and Bloomfield CD: Expression of the neural cell adhesion molecule CD56 is associated with short remission duration and survival in acute myeloid leukemia with $\mathrm{t}(8 ; 21)(\mathrm{q} 22 ; \mathrm{q} 22)$. Blood 90: 1643-1648, 1997.

57. Montesinos P, Rayón C, Vellenga E, Brunet S, González J, González M, Holowiecka A, Esteve J, Bergua J, González JD, et al: Clinical significance of CD56 expression in patients with acute promyelocytic leukemia treated with all-trans retinoic acid and anthracycline-based regimens. Blood 117: 1799-1805, 2011.

58. Ferrara F, Morabito F, Martino B, Specchia G, Liso V, Nobile F, Boccuni P, Di Noto R, Pane F, Annunziata M, et al: CD56 expression is an indicator of poor clinical outcome in patients with acute promyelocytic leukemia treated with simultaneous all-trans-retinoic acid and chemotherapy. J Clin Oncol 18: 1295-1300, 2000.

59. Ito S, Ishida Y, Oyake T, Satoh M, Aoki Y, Kowata S, Uchiyama T, Enomoto S, Sugawara T, Numaoka H, et al: Clinical and biological significance of CD56 antigen expression in acute promyelocytic leukemia. Leuk Lymphoma 45: 1783-1789, 2004.

60. Murray CK, Estey E, Paietta E, Howard RS, Edenfield WJ, Pierce S, Mann KP, Bolan C and Byrd JC: CD56 expression in acute promyelocytic leukemia: A possible indicator of poor treatment outcome? J Clin Oncol 17: 293-297, 1999.

61. Breccia M, De Propris MS, Minotti C, Stefanizzi C, Raponi S, Colafigli G, Latagliata R, Guarini A and Foà R: Aberrant phenotypic expression of CD15 and CD56 identifies poor prognostic acute promyelocytic leukemia patients. Leuk Res 38: 194-197, 2014.

62. Hills RK, Castaigne S, Appelbaum FR, Delaunay J, Petersdorf S Othus M, Estey EH, Dombret H, Chevret S, Ifrah N, et al: Addition of gemtuzumab ozogamicin to induction chemotherapy in adult patients with acute myeloid leukaemia: A meta-analysis of individual patient data from randomised controlled trials. Lancet Oncol 15: 986-996, 2014.

63. Breccia M, De Propris MS, Stefanizzi C, Raponi S, Molica M, Colafigli G, Minotti C, Latagliata R, Diverio D, Guarini A and Foà R: Negative prognostic value of CD34 antigen also if expressed on a small population of acute promyelocitic leukemia cells. Ann Hematol 93: 1819-1823, 2014.

64. Paietta E: Expression of cell-surface antigens in acute promyelocytic leukaemia. Best Pract Res Clin Haematol 16: 369-385, 2003

65. Xu F, Yin CX, Wang CL, Jiang XJ, Jiang L, Wang ZX, Yi ZS, Huang KK and Meng FY: Immunophenotypes and immune markers associated with acute promyelocytic leukemia prognosis. Dis Markers 2014: 421906, 2014.

66. Ahmad EI, Akl HK, Hashem ME and Elgohary TA: The biological characteristics of adult CD34+ acute promyelocytic leukemia. Med Oncol 29: 1119-1126, 2012. 
67. Grimwade D, Outram SV, Flora R, Ings SJ, Pizzey AR, Morilla R, Craddock CF, Linch DC and Solomon E: The T-lineage-affiliated CD2 gene lies within an open chromatin environment in acute promyelocytic leukemia cells. Cancer Res 62: 4730-4735, 2002.

68. Sunter NJ, Scott K, Hills R, Grimwade D, Taylor S, Worrillow LJ, Fordham SE, Forster VJ, Jackson G, Bomken S, et al: A functional variant in the core promoter of the CD95 cell death receptor gene predicts prognosis in acute promyelocytic leukemia. Blood 119: 196-205, 2012

69. Rowley JD, Golomb HM and Dougherty C: 15/17 translocation, a consistent chromosomal change in acute promyelocytic leukaemia. Lancet 1: 549-550, 1977.

70. Grimwade D, Biondi A, Mozziconacci MJ, et al: Characterisation of acute promyelocytic leukaemia (APL) cases lacking the classical $t(15 ; 17)$ : Results of the European working party 92: 677A-677A, 1998

71. Schoch C, Haferlach T, Haase D, Fonatsch C, Löffler H, Schlegelberger B, Staib P, Sauerland MC, Heinecke A, Büchner T, et al: Patients with de novo, acute myeloid leukaemia and complex karyotype aberrations show a poor prognosis despite intensive treatment: A study of 90 patients. Br J Haematol 112 $118-126,2001$

72. Grimwade D, Howe K, Langabeer S, Davies L, Oliver F, Walker H, Swirsky D, Wheatley K, Goldstone A, Burnett A and Solomon E: Establishing the presence of the $t(15 ; 17)$ in suspected acute promyelocytic leukaemia: Cytogenetic, molecular and PML immunofluorescence assessment of patients entered into the M.R.C. ATRA trial. M.R.C. Adult Leukaemia Working Party. ATRA trial. Br J Haematol 94: 557-573, 1996.

73. De Botton S, Chevret S, Sanz M, Dombret H, Thomas X, Guerci A, Fey M, Rayon C, Huguet F, Sotto JJ, et al: Additional chromosomal abnormalities in patients with acute promyelocytic leukaemia (APL) do not confer poor prognosis: Results of APL 93 trial. Br J Haematol 111: 801-806, 2000.

74. Slack JL, Arthur DC, Lawrence D, Mrózek K, Mayer RJ, Davey FR, Tantravahi R, Pettenati MJ, Bigner S, Carroll AJ, et al: Secondary cytogenetic changes in acute promyelocytic leukemia-Prognostic importance in patients treated with chemotherapy alone and association with the intron 3 breakpoint of the PML gene: A cancer and leukemia group B study. J Clin Oncol 15: 1786-1795, 1997.

75. Mi Y, Xue Y, Yu W, Liu S, Zhao Y, Meng Q, Bian S and Wang J: Therapeutic experience of adult acute myeloid leukemia in a single institution of China and its relationship with chromosome karyotype. Leuk Lymphoma 49: 524-530, 2008.

76. Pantic M, Novak A, Marisavljevic D, Djordjevic V, Elezovic I, Vidovic A and Colovic M: Additional chromosome aberrations in acute promyelocytic leukemia: Characteristics and prognostic influence. Med Oncol 17: 307-313, 2000.

77. Lo-Coco F, Avvisati G, Vignetti M, Thiede C, Orlando SM, Iacobelli S, Ferrara F, Fazi P, Cicconi L, Di Bona E, et al: Retinoic acid and arsenic trioxide for acute promyelocytic leukemia. $\mathrm{N}$ Engl J Med 369: 112-21, 2013.

78. Samir MD, Pedro H and Ling Z: Tetraploidy acute promyelocytic leuemia with double $t(15 ; 17) /$ PML-RARA, a case report with review of literature. Genes Chromosomes Cancer 46: 635-643, 2007.

79. Neto WK, Serpa M, Sanabani SS, Bueno PT, Velloso ED, Dorlhiac-Llacer PE and Bendit I: Early detection of $\mathrm{t}(8 ; 21)$ chromosomal translocations during treatment of PML-RARA positive acute promyelocytic leukemia: A case study. Clin Med Insights Oncol 4: 163-170, 2010.

80. Charrin C, Ritouet D, Campos L, Devaux Y, Archimbaud E, Fraisse J, Fiere D and Germain D: Association of $t(15 ; 17)$ and $t(8 ; 21)$ in the initial phase of an acute promyelocytic leukemia. Cancer Genet Cytogenet 58: 177-180, 1992.

81. Bonomi R, Giordano H, del Pilar Moreno M, Bodega E, Landoni AI, Gallagher $\mathrm{R}$ and del Rosario Uriarte $\mathrm{M}$ : Simultaneous PML/RARalpha and AML1/ETO expression with $t(15 ; 17)$ at onset and relapse with only $t(8 ; 21)$ in an acute promyelocytic leukemia patient. Cancer Genet Cytogenet 123: 41-43, 2000.

82. Varella-Garcia M, Brizard F, Roche J, Flandrin G, Drabkin $H$ and Brizard A: Aml1/ETO and Pml/RARA rearrangements in a case of AML-M2 acute myeloblastic leukemia with $\mathrm{t}(15 ; 17)$. Leuk Lymphoma 33: 403-406, 2009.

83. Xu L, Zhao WL, Xiong SM, Su XY, Zhao M, Wang C, Gao YR, Niu C, Cao Q, Gu BW, et al: Molecular cytogenetic characterization and clinical relevance of additional, complex and/or variant chromosome abnormalities in acute promyelocytic leukemia. Leukemia 15: 1359-1368, 2001.
84. Uz B, Eliacık E, Isık A, Aksu S, Büyükasık Y, Haznedaroğlu IC, Göker H, Sayınalp N and Ozcebe Oİ: Co-expression of $\mathrm{t}(15 ; 17)$ and $t(8 ; 21)$ in a case of acute Promyelocytic leukemia: Review of the literature. Turk J Haematol 30: 400-404, 2013.

85. Hu X, Ai G, Meng X, Hou J, Wei R, Tao Y, Zhang Q, Han Y and Shi J: An ider(17)(q10)t(15;17) with spliced long-type PML-RARA fusion transcripts in a case of acute promyelocytic leukemia. Cancer Genet 207: 253-257, 2014

86. Lee GY, Christina S, Tien SL, Ghafar AB, Hwang W, Lim LC and Lim TH: Acute promyelocytic leukemia with PML-RARA fusion on $\mathrm{i}(17 \mathrm{q})$ and therapy-related acute myeloid leukemia. Cancer Genet Cytogenet 159: 129-136, 2005.

87. Im SA, Kim SH, Lee MA, Ahn JY, Yoo ES, Choi DY, Lee JY, Lee S, Huh JW, Chung WS, et al: Identification of ider[17q] in addition to $\mathrm{t}[15 ; 17]$ in acute promyelocytic leukemia using whole chromosome painting probes made by interspecies hybrid using inter-Alu PCR. Cancer Genet Cytogenet 118: 169-170, 2000.

88. Kim MJ, Cho SY, Lim G, Yoon HS, Lee HJ, Suh JT, Lee J, Lee WI, Cho KS and Park TS: A rare case of Microgranular acute Promyelocytic leukemia associated with ider(17)(q10) $\mathrm{t}(15 ; 17)$ in an old-age patient. Korean J Lab Med 31: 86-90, 2011

89. Kim M, Lee SA, Park HI, Oh EJ, Park CW, Lim J, Han K and Kim Y: Two distinct clonal populations in acute promyelocytic leukemia, one involving chromosome 17 and the other involving an isochromosome 17. Cancer Genet Cytogenet 197: 185-188, 2010.

90. Kim MJ, Yoon HS, Cho SY, Lee HJ, Suh JT, Lee J, Yoon HJ, Lee WI and Park TS: ider(17)(q10)t(15;17) associated with relapse and poor prognosis in a pediatric patient with acute promyelocytic leukemia. Cancer Genet Cytogenet 201: 116-121, 2010.

91. Manola KN, Karakosta M, Sambani C, Terzoudi G, Pagoni M, Gatsa E and Papaioannou M: Isochromosome $\operatorname{der}(17)(\mathrm{q} 10) \mathrm{t}(15 ; 17)$ in acute promyelocytic leukemia resulting in an additional copy of the RARA-PML fusion gene: Report of 4 cases and review of the literature. Acta Haematol 123: 162-170, 2010.

92. Okoshi Y, Akiyama H, Kono N, Matsumura T, Mizuchi D, Mori S, Ohashi K and Sakamaki H: Effect of additional chromosomal abnormalities in acute promyelocytic leukemia treated with all-trans-retinoic acid: A report of 17 patients. Int $\mathbf{J}$ Hematol 73: 496-501, 2001.

93. Qiu HR, Li JY, Miao KR, Wang R and Xu W: Clinical and laboratory studies of an acute promyelocytic leukemia patient with double ider(17q) chromosome aberration. Cancer Genet Cytogenet 184: 74-75, 2008.

94. Schoch C, Haase D, Haferlach T, Freund M, Link H, Lengfelder E, Löffler H, Büchner T and Fonatsch C: Incidence and implication of additional chromosome aberrations in acute promyelocytic leukaemia with translocation $\mathrm{t}(15 ; 17)(\mathrm{q} 22 ; \mathrm{q} 21)$ : A report on 50 patients. Br J Haematol 94: 493-500, 2015

95. Tong H, Li K, Mei C, Wang H, Chen Z and Jin J: Arsenic trioxide may improve the prognosis of APL with ider(17)(q10): Report of a rare adult case of acute promyelocytic leukemia with ider(17) (q10)t(15;17) showing poor response to all-trans retinoic acid. Ann Hematol 90: 1493-1494, 2011.

96. Wan TS, So CC, Hui KC, Yip SF, Ma ES and Chan LC: Diagnostic utility of dual fusion PML/RARalpha translocation DNA probe (D-FISH) in acute promyelocytic leukemia. Oncol Rep 17: 799-805, 2007.

97. Sainty D, Liso V, Cantù-Rajnoldi A, Head D, Mozziconacci MJ, Arnoulet C, Benattar L, Fenu S, Mancini M, Duchayne E, et al: A new morphologic classification system for acute promyelocytic leukemia distinguishes cases with underlying PLZF/RARA gene rearrangements. Blood 96: 1287-1296, 2000.

98. Tan Y, Bian S, Xu Z, Chen X, Qi X, Ren F, Li L, Guo H, Xu A, Zhang $\mathrm{L}$ and Wang $\mathrm{H}$ : The short isoform of the long-type PML-RARA, fusion gene in acute promyelocytic leukaemia lacks sensitivity to all-trans-retinoic acid. Br J Haematol 162: 93-97, 2013.

99. Rosati R, La Starza R, Veronese A, Aventin A, Schwienbacher C, Vallespi T, Negrini M, Martelli MF and Mecucci C: NUP98 is fused to the NSD3 gene in acute myeloid leukemia associated with $\mathrm{t}(8 ; 11)(\mathrm{p} 11.2 ; \mathrm{p} 15)$. Blood 99: 3857-3860, 2002.

100. Ågerstam H, Lilljebjörn H, Lassen C, Swedin A, Richter J, Vandenberghe $\mathrm{P}$, Johansson $\mathrm{B}$ and Fioretos T: Fusion gene-mediated truncation of RUNX1, as a potential mechanism underlying disease progression in the $8 \mathrm{p} 11$ myeloproliferative syndrome. Genes Chromosomes Cancer 46: 635-643, 2007.

101. Otero L, Terra B, Diniz C, Abdelhay E and Fernandez Tde S: Dicentric $\mathrm{t}(8 ; 13)(\mathrm{q} 10 ; \mathrm{q} 10)$ as an additional chromosomal abnormality in a case of acute promyelocytic leukemia with very poor outcome. Leuk Lymphoma 50: 287-289, 2009. 
102. Adams J and Nassiri M: Acute promyelocytic Leukemia: A review and discussion of variant translocations. Arch Pathol Lab Med 139: 1308-1313, 2015

103. Corey SJ, Locker J, Oliveri DR, Shekhter-Levin S, Redner RL, Penchansky L and Gollin SM: A non-classical translocation involving $17 \mathrm{q} 12$ (retinoic acid receptor alpha) in acute promyelocytic leukemia (APML) with atypical features. Leukemia 8: 1350-1353, 1994

104. Yamanouchi J, Hato T, Niiya T, Miyoshi K, Azuma T, Sakai I and Yasukawa M: A new four-way variant $\mathrm{t}(5 ; 17 ; 15 ; 20)$ (q33;q12;q22;q11.2) in acute promyelocytic leukemia. Int $\mathbf{J}$ Hematol 94: 395-398, 2011.

105. Qiu HR, Li JY, Miao KR, Wang R, Zhang JF and Xu W: A case of acute promyelocytic leukemia with variant $\mathrm{t}(5 ; 17)$ and trisomy 22. Zhonghua Yi Xue Yi Chuan Xue Za Zhi 25: 430-433, 2008 (In Chinese).

106. Messmer BT, Messmer D, Allen SL, Kolitz JE, Kudalkar P, Cesar D, Murphy EJ, Koduru P, Ferrarini M, Zupo S, et al: In vivo measurements document the dynamic cellular kinetics of chronic lymphocytic leukemia B cells. J Clin Invest 115 755-764, 2005.

107. Ross DA and Kadesch T: The notch intracellular domain can function as a coactivator for LEF-1. Mol Cell Biol 21: 7537-7544, 2001.

108. Holland JD, Klaus A, Garratt AN and Birchmeier W: Wnt signaling in stem and cancer stem cells. Curr Opin Cell Biol 25: 254-264, 2013.

109. Petropoulos K, Arseni N, Schessl C, Stadler CR, Rawat VP, Deshpande AJ, Heilmeier B, Hiddemann W, Quintanilla-Martinez L, Bohlander SK, et al: A novel role for Lef-1, a central transcription mediator of Wnt signaling, in leukemogenesis. J Exp Med 205: 515-522, 2008.

110. Skokowa J, Cario G,Uenalan M,Schambach A, Germeshausen M Battmer K, Zeidler C, Lehmann U, Eder M, Baum C, et al: LEF-1 is crucial for neutrophil granulocytopoiesis and its expression is severely reduced in congenital neutropenia. Nat Med 12: 1191-1197, 2006.

111. Albano F, Zagaria A, Anelli L, Orsini P, Minervini CF, Impera L, Casieri P, Coccaro N, Tota G, Brunetti C, et al: Lymphoid enhancer binding factor-1 (LEF1) expression as a prognostic factor in adult acute promyelocytic leukemia. Oncotarget 5: 649-658, 2014.
112. Müller-Tidow C, Steffen B, Cauvet T, Tickenbrock L, Ji P, Diederichs S, Sargin B, Köhler G, Stelljes M, Puccetti E, et al: Translocation products in acute myeloid leukemia activate the Wnt signaling pathway in hematopoietic cells. Mol Cell Biol 24: 2890-2904, 2004.

113. Zhang Y, Yu J, Shi C, Huang Y, Wang Y, Yang T and Yang J: Lef1 contributes to the differentiation of bulge stem cells by nuclear translocation and cross-talk with the Notch signaling pathway. Int J Med Sci 10: 738-746, 2013.

114. Payton JE, Grieselhuber NR, Chang LW, Murakami M, Geiss GK, Link DC, Nagarajan R, Watson MA and Ley TJ: High throughput digital quantification of mRNA abundance in primary human acute myeloid leukemia samples. J Clin Invest 119: 1714-1726, 2009.

115. Alcalay M, Meani N, Gelmetti V, Fantozzi A, Fagioli M, Orleth A, Riganelli D, Sebastiani C, Cappelli E, Casciari C, et al: Acute myeloid leukemia fusion proteins deregulate genes involved in stem cell maintenance and DNA repair. J Clin Invest 112: 1751-1761, 2003

116. Avvisati G, Lo-Coco F, Paoloni FP, Petti MC, Diverio D, Vignetti M, Latagliata R, Specchia G, Baccarani M, Di Bona E, et al: AIDA 0493 protocol for newly diagnosed acute promyelocytic leukemia: Very long-term results and role of maintenance. Blood 117: 4716-4725, 2011.

117. Lo-Coco F, Avvisati G, Vignetti M, Breccia M, Gallo E, Rambaldi A, Paoloni F, Fioritoni G, Ferrara F, Specchia G, et al: Front-line treatment of acute promyelocytic leukemia with AIDA induction followed by risk-adapted consolidation for adults younger than 61 years: Results of the AIDA-2000 trial of the GIMEMA Group. Blood 116: 3171-3179, 2010. 